\title{
VALUE INNOVATION: NEW ENTRANTS AND CHAIN RESTRUCTURING IN AUSTRALIA'S EXPORT COAL CHAINS
}

\author{
Sophia EVERETT*, Ross ROBINSONE**
}

\begin{abstract}
Recently, the entry of new players has prompted significant restructuring in the Australian coal market with value migrating away from the existing fragmented, traditional production/export model characterised by competing operators generally using 'common user' infrastructure facilities to new, fully integrated supply chains creating a multi-tiered production-consumer framework.

This paper argues that not only are coal markets restructuring but they are doing so within the framework of a significant paradigm shift towards efficiency-seeking and efficiency-driven mechanisms. Value innovation and a deregulated market are enabling operators to enter the industry seeking and implementing end-to-end control of the supply chain - and, in so doing, capturing the significant gains of integration.

This paper explores these changes within the framework of integrative efficiency - a product of end-to-end control by a single party, derived from a number of companies, or chain elements, working cooperatively rather than competitively, or a single operator vertically integrating the chain from point of production to point of consumption to capture and deliver significantly higher value. The paper focuses attention on this paradigmatic shift in a brief though detailed case study of a major new industry entrant into export coal chains from the rapidly developing Galilee Basin in northern Queensland. It examines the dynamics and implications of this shift in the context of chain efficiency and value innovation
\end{abstract}

Keywords: Value innovation; integrated supply and value chains, bulk ports; coal chains; chain control; integrative efficiency

JEL classification numbers: L90, M19, O31

Submission Date: 08/10/2012 Revision Date: 07/12/2012 Acceptance Date: 23/12/2012

* Professorial Research Fellow, Institute for Supply Chain and Logistics, Victoria University, Melbourne, Australia . Email: Sophia.Everett@vu.edu.au

** Professorial Research Fellow, Institute for Supply Chain and Logistics, Victoria University, Melbourne, Australia. Email: Ross.Robinson@vu.edu.au 


\section{INTRODUCTION}

The present resources boom has seen Australia emerge as the world's largest coal exporter with tonnages projected to exceed 390 million tonnes by 2015 (ABARE 2010). Unprecedented growth driven by emerging economies, particularly China and India, is forecast to continue with metallurgical coal tonnages growing by 22 percent and a 42 percent growth in thermal coal by 2015. This growth, associated with the expansion of existing operations and the development of new mines, has placed significant pressure on existing export infrastructure - and particularly on rail and ports. As a result, a spate of new ports, terminals and rail lines are either in the planning stage or under construction.

These developments have led to significant changes in market structure and have seen large scale investment from overseas sources, in particular from China and India, seeking either to ensure a reliable source of supply to meet future needs or to benefit from the resources boom. No longer is the coal industry predominantly characterised by a relatively small number of highly competitive mining companies exporting to overseas customers, usually by means of fragmented and somewhat 'disintegrated' chains - though, in some cases with interests in and control over export terminals. Rather, the industry is undergoing a process of rationalisation and consolidation with traditional, relatively smaller mid-tier producers becoming takeover targets of larger, global operators. In addition, a spate of investment from local and overseas sources is opening up new fields - particularly, but not only in northern Queensland and notably in the Galilee Basin. This restructure has seen a dramatic increase in size and scope of both producers and consumers. It has, in particular, seen the entry of new players adopting different business models seeking the benefits of end to end supply chain control. Post deregulation, and in the light of continuing high levels of demand, it is now becoming clear that value is migrating away from the existing fragmented, production/export model characterised by a number of competing operators for the most part using 'common user' facilities to integrating value chains to a new model of fully integrated, end-to-end supply and value chains. Now, the entry of new, very large companies and global operators with significant advantage of scale, scope and market power are creating and occupying new market space with effective strategies for fully integrated, end-to-end control over the chain from point of production to point of consumption.

The growing demand for Australian coal is leading also to significant changes in the port environment. Growth at the beginning of the current resources boom, particularly from 2004 onwards, created inefficiencies in the chain manifest at the port/ship interface as demand exceeded chain, particularly terminal, capacity. Congestion, 
delays at terminals and ship queues of up to seventy vessels at any one time at a number of ports were endemic. A number of operating strategies were set in place at the time in an endeavour to resolve the bottlenecks; but in the event exceptional chain inefficiencies attracted the attention of the federal regulator under the provisions of the Trade Practices Act 1974. As a consequence some terminals and their associated export coal supply chains were regulated as demand pull systems rationing coal export tonnages and system capacity in an attempt to coordinate coal availability at the port with ship arrival (Robinson 2007). This, in a sense, artificial integrating mechanism, provided some relief in the short term but failed to resolve the problem in the longer term for Queensland supply chains as demand continued to outstrip both chain and port capacity (Everett and Robinson 2010).

New entrants are restructuring the industry and introducing changes in the traditional producer/buyer model as buyers and customers are investing heavily in mining and export infrastructure. A paradigm shift is occurring in which value is sought and delivered not from operational efficiency per se but from integrative efficiency (Robinson et al, 2012) - in effect, the development of chains in which all functional elements are coordinated by a 'single entity or intelligence' focusing not only on operational efficiency but also on investment efficiency.

Value is migrating from outmoded business designs to new ones appropriate to meet changing market demands and satisfy customers' most important priorities. While traditional mining companies continue to exist, albeit with reducing market share, value is migrating to large incumbent operators or to new entrants investing not only in mining operations per se but in the functional operations of the entire chain.

These developments have seen value in the industry shift over time from the delivery of an individual logistics functions by a corporate operator to control over sets of logistics functions. The landside freight handling market, particularly in a resources sector under pressure, is recreating itself - it is doing different things and it is doing things differently. The new value is in the 'integration' of functions and is increasingly in the hands of the integrators - of those whose new business model or design can offer customers superior value. The exceptional change is that efficiency of specific logistics functions, such as an efficient mining or rail operation, is no longer seen as the priority or core business objective. Rather the new strategic imperative is 'integrative efficiency' - creating new value and market space.

These developments are, in effect, creating a multi-tier system in the coal sector and in the following section we document, albeit briefly, the background to the recent changes in the Australian coal industry; and in Sections 3 and 4 we look more closely at a framework for interpretation of change and focus on a case study of a major new entrant into the Galilee Basin. 


\section{CHANGE IN AUSTRALIA'S COAL INDUSTRY: A BACKGROUND NOTE.}

\subsection{The move to exports}

Australia has a relatively short coal export history as production up to the 1970s was primarily for domestic consumption - mining operations were captive to the local steel and manufacturing industries and electricity generation. Some relatively small tonnages of metallurgical coal had been exported to Europe in the 1960s but significant growth in export markets did not occur until later in that decade in response to demand from developing Asian economies, particularly steel mills in Japan. The export of thermal coal from Australia did not begin until the 1970s and was triggered by the oil crises in that decade - 1973 and 1979/80 - which resulted in sharp increases in the price of oil when the Organisation of the Petroleum Exporting Countries (OPEC) cut supply and thermal coal began to replace oil for electricity generation in many overseas power stations. This led to the rapid development of the thermal coal export industry in Australia.

\subsection{Mining companies}

The ownership and operation of coal mines at the time was generally with traditional resources companies such as Broken Hill Proprietary Ltd (subsequently BHP Billiton) and Rio Tinto (at the time CRA) as well as a large number of small to mid tier operators. BHP owned metallurgical coal mines captive to the company's steel making operations and any surplus tonnage was exported. Rio Tinto's production, on the other hand, was sold on a contract basis. The oil crises of the 1970s saw the expansion of thermal coal production by traditional mining companies such as BHP and Rio Tinto, for example, but also saw energy producers enter the market seeking to capture the benefits of the growing demand and a newly emerging industry - oil companies such as Shell and BP, for example, began to invest in thermal coal mines in Australia, particularly in the Hunter Valley of New South Wales.

In the last decade Australia has experienced significant overseas investment in the coal industry and although the scale of investment is unprecedented it is not a new phenomenon as Australia has a history of overseas investment in coal mining and export back to the 1960s. Clutha Development Corporation, for example, was a major developer of the coal industry in New South Wales in the 1960s and Utah Coal, a subsidiary of General Electric, was one of the pioneers in Queensland's Bowen Basin in the 1970s. Overseas investment from Asian sources also emerged at that time Mitsubishi, Nippon Steel, Mitsui, for example, were major customers of Australian coal 
producers and consumers, particularly of metallurgical coal, and formed joint ventures with local producers (Everett 1987). These joint ventures tended to be between producers and customer/consumers investing in the industry to ensure supply.

\subsection{Infrastructure ownership}

Up to 2000 coal export infrastructure was a mix of public and private ownership. Ports were generally owned and operated by state governments although some privately owned terminals had been established operating as dedicated facilities - Utah's export terminal in the port of Mackay, Hay Point Coal Terminal, for example, was captive to the company's coal mines. Although the company in this instance owned the mines as well as the terminal, it was not a fully integrated operation, as is occurring at present as the government of Queensland had monopoly control over all rail operations in that state, including coal haulage.

The two terminals in the port of Newcastle, Port Waratah Coal Services and Kooragang Island Coal Terminal, were also privately owned but were 'common user' facilities. These were owned and operated by two consortia each comprising coal companies and Asian customers (Everett 1987). Other terminals along Australia's east coast, Port Kembla, Brisbane, Gladstone, Dalrymple Bay Coal Terminal and Abbot point were all government owned and operated until government embarked on a program of deregulation in the 1990s (Everett and Robinson 1995). By 2000 these facilities, with the exception of the port of Gladstone, had either been privatised or decommissioned and replaced with new terminals. At the present time the port of Gladstone is the only publicly owned and operated coal port in Australia although privately owned terminals are under construction in that port - Wiggins Island and Balaclava Island, for example.

Railways in Australia, like the ports, were traditionally built by colonial and later state governments. Each state had its own rail network and until the 1990s state governments had sole jurisdiction over rail operations within their respective borders. Commercialisation strategies had been set in place in the late 1980s which was a precursor to corporatisation and ultimately privatisation. All former government owned railways are now privately owned - a necessary, though not sufficient, condition for the subsequent integration of chains. Note that in some states in Australia the track or 'below rail' - and associated infrastructure are publicly owned. The rail track in the Hunter Valley carrying coal to the port of Newcastle, for example, is owned and operated by the Australian Rail Track Corporation, a commonwealth government owned company. In other states, such as Queensland, the track was privatised together with 'above rail' operations. 


\subsection{Changing market structure}

Australia has now emerged as the world's largest resources exporter with coal tonnages expected to exceed 320mt in 2012 and reach 390mt by 2015 (ABARE 2010) - and iron ore exports at that time are projected to be in the vicinity of $476 \mathrm{mt}$ (DFAT2010). This unprecedented demand has led to significant changes in market structure with the opening up of new coal fields, the development of new mines, expansion of existing operations and the recommissioning of older mines which had become unprofitable and decommissioned in the past when production costs exceeded the landed price of coal.

In this environment the market is restructuring as the industry is increasingly dominated by large operators which, with significant financial backing, are acquiring a spate of small and mid tier companies. The industry in the past, as noted above, was characterised by a number of discrete operators performing a specific task or function in what was generally a segmented chain. Indeed, in most instances, they generally performed a single chain function-aminingoperation,forexample,ortheprovisionofara ilservice. This segmented chain frequently created network bottlenecks particularly when demand exceeded system capacity.

Although traditional mining companies continue to exist, albeit in fewer numbers and enjoying a shrinking market share, they are under threat and are take-over targets by large multinational organisations. A process of rationalisation and consolidation is, in fact, underway as value is migrating away from small to mid tier companies with outmoded business models in which operational efficiency was, in the past, the producers' criterion creating competitive advantage and delivering value to the customer. Value is now perceived to emanate from the delivery of an integrated, coordinated operation in which the producer has end to end control of the chain - indeed the new future focus, (Robinson (2012) suggests, should be on 'integrative' rather than 'operational' efficiency.

Rationalisation and consolidation in the industry is, in fact, threatening the continued existence of mid-size companies. De Lacy, former chairman of Macarthur Coal, argues 'There is little opportunity for mid-sized Australian-owned producers to flourish given the scale required to compete in an industry driven by rampant demand from China and India. This has created an environment in which only large companies can deliver and mid-size coal sector is endangered and prone to take-over particularly by foreign companies' (Australian Financial Review 21.12.11).

In recent years then a multi tier industry structure is emerging in which large, frequently overseas, companies have acquired a spate of small and mid tier operations. Yancoal Australia, for example, acquired Felix Resources in December 2009 for \$3.3 
billion. Felix Resources operated four mines in Queensland's Bowen Basin as well as the Ashton and Mootarben mines in the Hunter Valley. Recently Yancoal's parent company, the Hong Kong listed Yanzhou Coal, obtained approval from the Foreign Investment Review Board in Australia for the takeover of Gloucester Coal which owns two mines in the Gloucester Basin; exploration licenses and a 50 percent stake in Middlemount Mine in Queensland (Sydney Morning Herald 8.3.2012).

Banpu Public, a leading coal based energy player in the Asia-Pacific region, entered the Australian coal market in 2010 when it acquired Centennial Coal, a major thermal coal producer. Banpu now owns, either in full or as a joint venture, five mines in the Hunter Valley and six mines in the Lithgow region - all thermal coal operations supplying both the domestic and overseas markets.

Peabody Energy, a major supplier of seaborne thermal coal, acquired eight mines in Queensland and New South Wales. The company also has interests in metallurgical coal and in 2011 acquired Macarthur Coal for \$4.9 billion. Macarthur Coal had developed a niche export market for low volatile pulverised coal injection (PCI) technology used for steel making. PCI technology injects pulverised coal into blast furnaces as an auxiliary to metallurgical coal reducing operating costs in the production of pig iron and crude steel.

In addition, large established mining companies in Australia are all expanding by either acquiring existing operations or developing new projects. Xstrata's Wandoan Coal Project in Queensland's Surat Basin proposes the construction of a 30mtpa open-cut mine; the construction of the Surat Basin Rail to the port of Gladstone and new export terminals at Wiggins Island and Balaclava island. The Wandoan project with an estimated 4 billion tonnes of thermal coal resource is a joint venture between Xstrata (75 percent) and Japanese interests - ICRA (Itochu) Pty Ltd (12.5 percent and Sumisho Coal Australia (12.5 percent).

Growth in demand has led to investment securing a reliable supply in a global environment hungry for resources. Coal prices have exceeded $\$ 350 / t$ in recent years and an industry that generates approximately $\$ 40 \mathrm{~b}$ annually has attracted a spate of new type of investors. It has also opened up and is developing new coal regions such as the Galilee Basin in Queensland - the last undeveloped coal resource which is expected to become the largest coal producing region in that state. The potential value of the Galilee Basin with a rich source of good quality metallurgical and thermal coal was not unknown in the past but its remote location was a barrier to its development. The continued high coal prices in recent times and the continuing growing demand for the product has made the mining of these remote reserves viable (AustCoal Consulting Alliance 2010).

Clearly, changes in the industry have been pervasive and deep and it is critically 
important to describe them. But it is even more important to understand the drivers of change, to conceptualise the dynamics of change. In the following section we explore these issues.

\section{ONCEPTUALISING CHANGE: VALUE INNOVATION, INTEGRATIVE EFFICIENCY AND NEW MARKET SPACE}

In our view the simple but elegant notion of value innovation, a relatively recent strategic development framework developed by Kim and Mauborgne (2005), is of particular significance in providing insight into the issue of chain and market restructuring and we outline the key fundamentals of this conceptual framework. These authors have recognized that Schumpeterian innovation was endogenously driven - new technology and processes impact cost and change; and technology innovation 'typically sets high prices, limits access, and initially engages in price skimming to earn a premium on the innovation, only later focusing on lowering prices and costs to retain market share and discourage imitators' (Kim and Mauborgne 2005:213). For Kim and Mauborgne, however, value innovation is about creating new market space; it is 'about driving costs down while simultaneously driving value up for buyers. This is how a leap in value for both the company and its buyers is achieved. Because buyer value comes from the utility and price that the company offers to buyers and because the value to the company is generated from price and its cost structure, value innovation is achieved only when the whole system of the company's utility, price, and cost activities is properly aligned'. Further, '......value innovation is more than innovation. It is about strategy that embraces the entire system of a company's activities. Value innovation requires companies to orient the whole system toward achieving a leap in value for both buyers and themselves. Absent such an integral approach, innovation will remain divided from the core of strategy' (Kim and Mauborgne 2005:17)

Figure 1 provides a framework for conceptualising the change in chain and industry structures that we argue in respect of coal chains and the coal production market. At its core is the concept of value innovation - 'Value innovation is created in the region where a company's actions favourably affect both its cost structure and its value proposition to buyers. Cost savings are made by eliminating and reducing the factors an industry competed on. Buyer value is lifted by raising and creating elements the industry has never offered. Over time, costs are reduced further as scale economies kick in due to the high sales volumes that super value generates' (Kim and Mauborgne 2005:16).

In effect, the zone of value innovation shown represents the limits of a firm's 
value proposition to the buyer in terms of the cost/value trade-off on offer. The value innovation is delivered through whole-of-chain integration which, in turn, delivers 'integrative efficiency' - essentially that chain efficiency that delivers both operational and investment efficiency over the longer term. It is this 'integrative efficiency' which becomes the new benchmark for chain and industry firms - and, in fact, becomes the differentiating factor for coal firms 'playing in the market place'.

\section{Figure 1.}

Value innovation, new market space and chain restructure

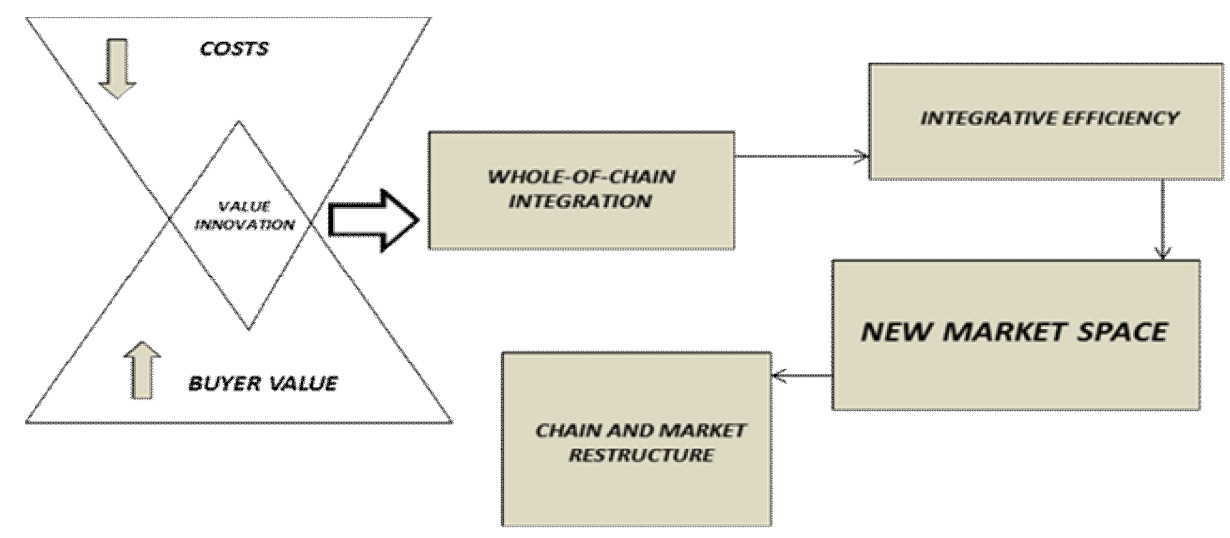

Not surprisingly, this new efficiency will restructure the market; leaders and laggards will emerge, the market will rationalise towards a 'steady state' - until further restructuring takes place.

Discussion of the Adani model below suggests that it perfectly represents the creation of new market space. It suggests the adoption of a totally new business model, a paradigm change in Kuhnian terms (Kuhn 1970), in which the operation is focused on total integration; in which functions are coordinated and under the control of a 'single intelligence' or operator.

\section{GALILEE BASIN AND EMERGING PARADIGM CHANGES: THE ADANI PHENOMEMON}

The market structure of the more recently emerging Australian coal industry, as noted, is dramatically different in 2012 compared with that a decade earlier. All rail 
infrastructure has been privatised and, with the exception of the port of Gladstone, all export terminals are privately owned. The latest mining developments in the Australian coal industry - in Queensland's Galilee Basin - is the largest coal deposit in that state with an estimated reserve of 2,200 billion tonnes (Appendix 1).

This latest development is driven by a number of players including established domestic and international mining companies as well as non-traditional coal companies investing in business ventures seeking profits in a rapidly expanding industry. Significant investment has also come from overseas companies, particularly from India and China, establishing either joint ventures with domestic operators, or as sole operators, with the objective of ensuring ongoing supply in a global environment hungry for resources. Hancock Coal's $\$ 8 \mathrm{~b}$ joint venture with GVK in India, for example, involves the development of two thermal coal mines, a $500 \mathrm{~km}$ rail line and dedicated port facilities at Abbot Point - this secures a source of thermal coal for GVK Power stations in India. Palmer's Waratah Coal project, similarly, is a joint venture with First China Coal which includes coal mines, rail and port facilities at an estimated cost of $\$ 6.55$ billion - this includes $\$ 2.1$ billion for a $490 \mathrm{~km}$ rail line, $\$ 3.8$ billion for mine development and $\$ 1.27$ billion for port construction. This development is funded up to 85 percent by China Eximbank, the export/import bank of China and is projected to produce 40mtpa of thermal coal providing fuel for China Power International Holding.

Most recent developments suggest the adoption of a quite different business model. In this case the firm is adopting a 'whole of system approach' integrating the firm's functional and operational activities. The investor is developing an integrated, purpose designed system which is linked directly from point of production in Australia to point of consumption in India. This is a fully integrated model in terms of ownership and control in which the company is the producer, the customer as well as the end user and controls all interconnecting links. This latest development constitutes a novel and innovative business model and design which is restructuring a market in which value has migrated away from traditional mining operations using 'common user' infrastructure to a chain which is fully integrated and captures value by controlling all parts from point of production to point of consumption.

The Adani Mining Pty Ltd (Adani) operation in the Galilee Basin is developing a business model designed to serve the company's needs in India and is a fully integrated owned and operated network. In 2011 Adani, following an international competitive bidding process, acquired the Abbot Point coal Terminal from the Queensland government for $\$ 1.8$ billion. This purchase was funded by the State Bank of India and the Standard Chartered Bank. In 2011 Adani entered the thermal coal market acquiring a 100 percent interest in the Carmichael Project in the Galilee Basin 
with a reserve of almost 8 billion tonnes. The Carmichael Project is a greenfield site which includes two mines which are under construction and are projected to jointly produce $60 \mathrm{mtpa}$ - these mines are estimated to have a life of approximately 100 years. The Carmichael Project is the largest investment by an Indian company in Australia and the single largest tenement in terms of coal resource. The mines will be commissioned in 2014 with initial exports of $2 \mathrm{mtpa}$ in that year and a phased increase to $60 \mathrm{mtpa}$ by 2022 .

The project entails the construction of two new rail lines - the Adani Railway, a $400 \mathrm{~km}$ greenfield rail corridor linking the mines to the port of Abbot Point. The second line links the Carmichael mines to the new port at Dudgeon Point adjacent to the port of Hay Point. Adani will construct a $175 \mathrm{~km}$ link from the Carmichael mines to the existing Goonyella network; proceed on the Goonyella line to the port at Hay Point from where the company will construct a new corridor to the company's dedicated terminal at Dudgeon Point. At the present time the existing Goonyella line is unable to carry these additional Adani tonnages but the Goonyella track is projected to be upgraded capable of carrying up to $230 \mathrm{mtpa}$ - this upgrade will be completed by the time Adani's annual export tonnages reaches $30 \mathrm{mt}$.

The Adani Carmichael project will have significant impact on Queensland's port facilities as the mines will be linked to two Adani owned dedicated export terminals as noted above, one at Abbot Point where the port is expanding with the construction of six new terminals one of which will be dedicated to the Adani operations. Adani will also have a dedicated terminal at the new port at Dudgeon Point. When completed this development will add an 150 - 180 mtpa capacity to the port.

At the Adani owned and operated terminals coal will be loaded onto Adani owned ships. The company will have a fleet of four Capesize vessels in 2012 - two vessels were commissioned in January 2011 and the third and fourth are due for delivery in 2012 .

The chain is also integrated at the customer end - the Mundra Port and Special Economic Zone Ltd, a multi-user port, is now a subsidiary of Adani Enterprises and renamed Adani Ports. The West Basin expansion in that port is a bulk import/export facility - this will be a phased development with twenty berths and the potential to handle $200 \mathrm{mtpa}$ of bulk cargo. The West Basin Terminal, built to meet the coal requirements for two mega power projects established by Adani Power and Tata Power, will comprise three capesize berths in phase 1 - two berths are operational at present and the third berth will be completed in 2012. The Mundra development will include a $64 \mathrm{~km}$ rail line which connects the port with the national network and Adani power stations - which are anticipated to be generating 20,000 MW by 2020.

This Adani model is the quintessential intra-firm international coal chain. It is 
wholly integrated, fully coordinated chain between and across two continents, owned, operated and under the control of a single monopoly operator.

The Adani totally integrated coal - power generation chain is the first development of its type in Australia. It surpasses the BHPB Pilbara iron ore model in which ownership is restricted to the mines, railway, terminal and, under CFR contracts of sale, the shipping leg under ship charter arrangement. The Adani model has gone beyond this as it has control over the mining operation, rail, port at the production end and shipping, port and rail in India fuelling Adani owned power generation plants - a fully integrated end-to-end intra-company operation. The model has been erroneously referred to as a 'pit to port' operation but it is more than that for, unlike the iron ore chain, the model does not finish at the discharge port or with the customer - under the Adani model, the company is the producer, the customer and is also the consumer.

\section{CONCLUDING COMMENTS}

Considerable restructuring has occurred in the Australian coal export market which has led to the development of a multi-tier production framework. This represents a significant paradigm shift from a market which in the past consisted of a relatively large number of small to mid size companies and a smaller number of large operators to one which is increasingly dominated by the entry of a growing number of large global multinationals.

Recent investment in the industry has seen the opening up of greenfield sites seeking efficiency with control of the entire chain. Large global operators are capturing and occupying new market space with effective strategies for fully integrated end to end control over the chain from point of production to point of consumption. In this context new value is sought in the integration of function - the objective of operational efficiency has been replaced with integrative efficiency. Incumbents in existing supply chains are unable to emulate this and until recent times their means of raising efficiency levels has been with the transition from supply push to demand pull models (Robinson 2007).

What are the implications of this emerging restructured market? The Adani model is innovative - it is innovative in ownership and in linking production with consumption in a global network. The company's strategy is the control of the entire system adopting a model that delivers 'integrative efficiency' - the new benchmark for not only a firm's but, perhaps more significantly, the chain's performance. Arguably, the new value lies in ownership and in integration, not merely in infrastructure 
integration but in the development of a chain in which functions are coordinated and under the control of a single operator - a 'single intelligence'.

What are the implications of this restructure on the smaller players? And what are the implications for incumbent operators in existing supply chains? Does the trend away from smaller to larger players mean that the coal industry, in the future, is restricted to the large global operators? Does it mean that integrative efficiency cannot be captured and implemented in existing coal chains where 'common user' infrastructure is the norm? While it is beyond doubt that the rationalisation and consolidation underway is threatening the survival of small to mid tier companies, it does not mean that relatively smaller companies in existing coal chains cannot continue to exist and capture value with the Adani model described in this paper.

There are limitations in existing coal chains as the ability to expand is finite existing coal chains both in Queensland and New South Wales are restricted as far as expansion is concerned. This means that emulating and applying the Adani model in so far as total control of all chain elements is difficult, if not impossible. That does not mean, however, that integrative integration is beyond the scope of existing chains for, arguably, the success for achieving this is not driven exclusively by ownership per se but by adopting and enforcing a collaborative approach by adopting an operating approach along the lines of a 'single intelligence'. In the past collaboration among chain partners has been attempted on a voluntary basis which has been less than successful. Regulated efficiency with the introduction of the export quota systems in Dalrymple Bay and in the port of Newcastle was effective, though not a long term solution. Robinson (2012) points to success achieved to date by the Hunter Valley Coal Chain Coordinator Ltd which, like the Adani model, focuses on the chain as a single operating entity which is achieving integrative efficiency with the establishment of a legally binding cooperative mechanism. 


\section{APPENDIX 1. QUEENSLAND'S COAL BASINS, MINES AND RELATED INFRASTRUCTURE.}

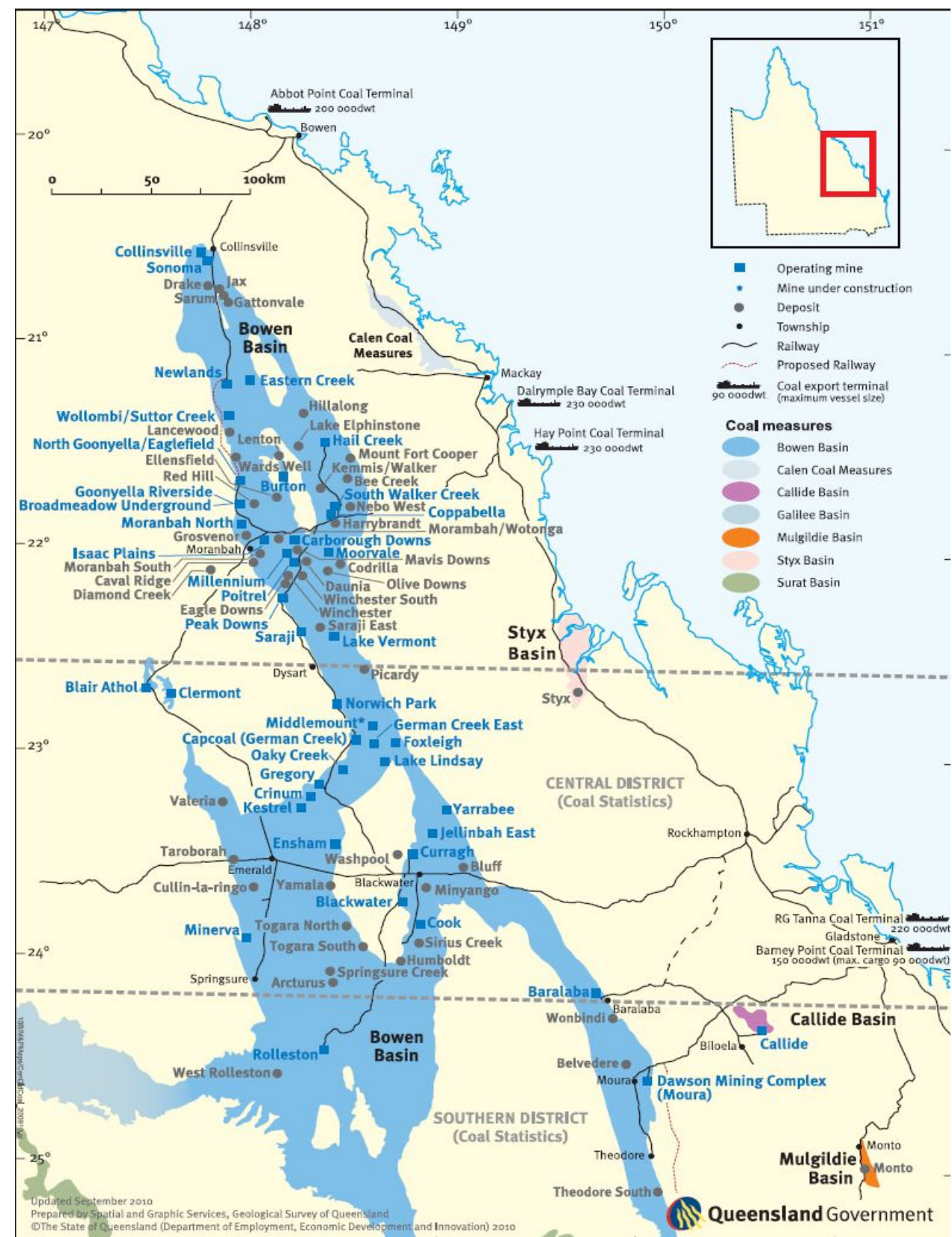




\section{REFERENCES}

Australian Financial Review 12.12.2011

AustCoal Consulting Alliance (2010) Australian coal export forecast to 2015 Responding to strong demand from China and India, December

Australian Bureau of Agricultural and Resource Economics (2010) Australian commodities, March Quarter

Department of Foreign Affairs and Trade (2010) Australia's coal and iron ore exports 1999 to 2009

Everett S (1987) The location of transport infrastructure and the policy-making process; port terminals and modal networks for NSW export coal in the post 1970s, Unpublished $\mathrm{PhD}$ thesis, University of Wollongong

Everett S and Robinson R (1995) 'Privatisation in ports: the Victoria and NSW experience' Australian Journal of Public Administration, December

Everett S and Robinson R (2010) 'Policy, politics and port efficiency: Insights from Australian port development strategies' Paper presented at the Annual Conference of the International Associationof Maritime Economists, Lisbon, July.

Kim WC and Mauborgne R (2005) Blue Ocean Strategy, Harvard Business School Press, Boston

Kuhn T (1970) The structure of scientific revolutions, The University of Chicago Press, Chicago

Robinson R (2007) Regulating efficiency into port-oriented chain systems: export coal through the Dalrymple Bay Terminal, Australia, Maririme Policy and Management, Vol 34, No 2,89-106.

Robinson R (2009) Chain systems analysis: new thinking about supply chain efficiency, Monograph Series in Chain Systems Analysis, The Centre for Integrated Freight Systems Management

Robinson R, Weston R and Everett S (2012) 'Port-oriented supply chain integration: critical efficiency issues' Paper presented at the Annual Conference of the International Association of Maritime Economists, Taipei, September

Sydney Morning Herald 8.3.2012 